Revista Iberoamericana, Vol. LXIX, Núm. 205, Octubre-Diciembre 2003, 895-908

\title{
ENRIQUE LAGUERRE Y LA MEMORIOSA CONSTRUCCIÓN DEL BLANQUITO EN LA LLAMARADA
}

\author{
POR \\ Lola Aponte Ramos \\ Universidad de Puerto Rico
}

A Ricardo José, hijo y memoria carnal

En sus comentarios sobre Piel negra, máscaras blancas de Franz Fanon, el crítico poscolonial Homi K. Bhabha propone que la memoria es el puente necesario y a la vez peligroso entre el colonialismo y el asunto de la identidad cultural. El gesto de recordar, escribe Bhabha, "is never a quiet act of introspection or retrospection. It is a painful remembering, a putting together of the dismembered past to make sense of the trauma of the present” (63). El recuento de Bhabha de la gramática del recuerdo se elabora sobre las percepciones provistas por el locus cognitivo psicoanalítico de que la memoria es el basamento sumergido y constitutivo de la existencia consciente. Siguiendo la mitología psicoanalítica elaborada a partir de Freud, para Bhabha mientras unas memorias tienen la cotidianidad y el espacio consciente como espacio de gravitación, otras son canceladas y deambulan por las periferias de lo inconsciente, a veces de manera peligrosa, causando malestares e interferencias molestosas. Esas memorias disturbantes, desde su cautiverio, envían síntomas, la más de las veces ofensivos.

Conviene apuntar que la tensión de lo pensado/lo no pensado subyacente, vital en el recuento del protagonismo de las memorias en las discursividades nacionales, acerca a Bhabha estrechamente a Lacan. Recordemos cómo, guiado por la lectura irónica del cogito ergo sum cartesiano, Lacan propone: "I think where I am not, therefore I am where I do not think" (166).

Este borramiento del yo pensante en paradoja con la insistencia del humanista racional que propone ser el personaje es probablemente la tensión más importante que atestiguamos en La llamarada de Enrique Laguerre, escritor puertorriqueño negro. Texto fundacional de las letras puertorriqueñas en su emergente modernidad, La llamarada propone la memoria reflexiva y sus máscaras como método escritural que da cuenta de la vida de un joven agrónomo montañés, Juan Antonio Borrás, en un latifundio del llano cañero. ${ }^{1}$ Atestiguamos, a través de un relato en primera persona, las contradicciones propias del desencanto con las utopías políticas y proyectos económicos, conjuntamente con las búsquedas amoroso-sociales del personaje.

\footnotetext{
${ }^{1}$ La llamarada forma parte del currículo escolar de la preparatoria de los estudiantes que asisten al sistema público de educación.
} 
La historia personal participa de la misma raigambre que la sociohistórica. Al final de la novela, Borrás decide casarse con una chica francesa (por su robustez garantizadora de una buena matrona), abandonar la caña por el café, y el llano por la montaña. Esto es, alejarse de la vida política, tras descubrir el concubinato entre dirigentes de bandos contrarios y, consecuentemente, la imposibilidad del cambio bajo el espacio institucionalizado. Mientras, se organiza en el espacio hogareño una postura programática de misogenación, regulación e higienización. Con ello, se continua un proceso de "dárselas de blanquito" -como se acuña en el lenguaje oral puertorriqueño para quienes asumen los valores de las capas altas- presente en todo el texto y que sigue diversas pulsaciones: reclamo de genealogía, el asedio a formas cognitivas validadas a partir de las descripciones étnicas, educativas o socioeconómicas de los personajes, el diseño de reglamentación de la sexualidad y la narrativa desde un plano de memoria autobiográfica entre otras. Este proceso relata conflictos y contradicciones que se intentan apañar en el relato de la simpatía por los puertorriqueños de clara ascendencia africana, siempre en posiciones serviles y cuyos reclamos son atemperados por la insistencia en un orden de mundo occidental, asumido como natural.

Nos enfrentamos a un texto en el que la memoria organiza e incluso suprime el mundo extensional. Así pues, la memoria se constituye en el mecanismo para ejercer la razón humanística en el proceso del sujeto de participar de las capas medias de poder. No deja de ser curioso, sin embargo, que Borrás, quien desconoce las historias subyacentes y la naturaleza del mundo que lo rodea, sea quien relate la historia; que sea precisamente sobre él, un personaje que vive una suerte de extranjería, sobre quien se deposite el caudal de la memoria. Se trata así de una memoria/desmemoria. La autoridad de la memoria relatada está vinculada a la escritura que a su vez es un mecanismo de suprimir otros posibles relatos, crear espacios de desmemoria. Así pues, la persistencia de las letras como memoria privilegiada nos permite sospechar de la desmemoria como gesto supresor de lo disturbante, por lo que la escritura se propone como un espacio liminar de pasaje entre el recuerdo y el olvido. De esta manera, en su ars poetica y razón de ser del texto que nos entrega Borrás, personaje relator, se expresa sobre la memoria y el relato de sus transformaciones: “[...] porque es bueno que se sepa que empecé a escribir las impresiones de mi estada en Santa Rosa desde el día que acaeció el incidente que les relataré más adelante. Las semanas antes de dicho incidente las pasé creyéndome un héroe del Oeste americano, sin una idea precisa de la situación” (61). En este fragmento el personaje no solo incide en la relación escritura / memoria, sino que propone una jerarquía de saberes que irá trabajando a lo largo del texto. Esta jerarquización de los saberes se dibuja sobre marcadores sociales racializados. Borrás en sus reflexiones complica sus supuestos humanistas -y la representación elaborada a partir de éstos- tanto con la exclusión de ciertos tipos de conocimiento como con su continua categorización de la gente, la que en algunos casos no es considerada adecuadamente representativa de lo humano. Estas exclusiones insidiosas no solo participan de la división entre conocimiento oral/escrito, académico/experiencia inmediata (división propia de los valores de Occidente), sino que a partir del gesto de la escritura y la construcción de la utopía desarrollista se refuerza una diferenciación entre el artesano y el educado, lo vivido y lo leído, división a la que subyace el asunto racial. 
En este punto es importante notar que la distinción propuesta por el personaje entre los descendientes de europeos educados y el resto de la población es central en su reflexión sobre la situación que reseña. Así pues, los parámetros de diferenciación entre los conocedores de los studia humanitatis y aquéllos cuyo dominio es el mecánico o el de lo experimentado/vivido, están cimentados en una discriminación política y racialmente encauzada. Esta división se sostiene, además, por la reflexión constante sobre la legitimidad de la tenencia de la tierra y de la portación y posesión de insignias que ello presupone.

La relación saber/tenencia de tierra linaje europeo adquiere su mayor relevancia cuando, al finalizar la novela, Borrás hereda un cafetal en la montaña y allí, bajo la constitución del poder del heredero de linaje claro y portador del studia humanitatis, el mundo es armónico. Tenemos pues que la herencia, confirmadora de linajes y legitimizadora de saberes, es decisiva en la constitución de los universos relatados pues mientras la tenencia de la industria de azúcar se da gracias a la apropiación por manejos turbios y la expulsión de los dueños legítimos -lo que conlleva una relación patrón-obrero de explotación y enajenación-, el mundo de la tenencia de tierra heredada se describe a partir de las fiestas del acabe y el paisaje de belleza llena de paz. ${ }^{2}$ Coincide la tenecia legitimadora con el matrimonio de Borrás y la francesa, esto es, la integración de su yo con el linaje europeo que reclama. Importante será subrayar que la vida del obrero que recoge el café ni siquiera es aludida, si bien la de su contraparte llanero era uno de los nudos narrativos centrales a la hora de Borrás asumir la narrativa de la caña.

Laguerre, al cederle la voz a un personaje como Borrás, nos muestra las contradicciones de un sujeto en ascenso en la escala social, de educación coartada, quien se apropia y firma la gramática de la distinción entre lo civilizado y lo barbárico. Esta división emborrona sus límites, pues si bien se favorece el espacio occidental, el mismo se cuestiona. Borrás, quien comienza siendo un fiel creyente del proyecto de educación y asimilación propuesto por Occidente y apropiado por las instituciones académicas de las que es producto, duda del mismo. Finalmente restituye su convicción en los studia humanitatis y su relato rastrea las convicciones y cuestionamientos inherentes a los espacios epistemológicos occidentales. Veamos.

En el caso de Borrás, el proyecto de construir su yo recuerda aquél de los studia humanitatis de Heidegger, quien en su "Carta sobre el humanismo" señala cómo el conocimiento humanístico siempre descansa en una oposición entre el espacio de la heteronormatividad del Homo humanus -con el cual se identifica plenamente Borrás- y el Homo barbarus -locus que asigna Borrás a Lope, la peonada, los políticos, en fin, al habitante del cañaveral. Mientras el personaje reclama su capacidad para producir conocimiento humano representativo del mundo que va adquiriendo y anotando, impone una serie de restricciones culturales, sociales y económicas que resultan en un discurso contradictorio de importantes aristas racializadas.

Con insistencia Juan Antonio Borrás valida su distinción del resto de los empleados de la industria cañera, tomando como médula de tal distinción su dominio de los studia

\footnotetext{
${ }^{2}$ La fiesta del acabe es una celebración para dar por finalizada la recogida del café, a manos de agregados -los sin tierra- que entonces se marchaban a otras fincas a prestar servicios. Hoy las fiestas son auspiciadas por el Intituto de Cultura, organismo estatal para la protección del folclore.
} 
humanitatis. Sin embargo, su gesta humanista carece de un instrumental para enfrentar adecuadamente los espacios prácticos de crisis, por ejemplo, la huelga que se desata en el predio cañero. Borrás se coloca, entonces, bajo la herencia recuperada tras la muerte del padre, y con ello asume su posicionalidad de blanco, pero carece de un vocabulario efectivo para domeñar el espacio de reestructuración de poderes que supone la modernidad. Curiosamente, dentro de la lógica textual estas contradicciones en la discursividad que palpitan por el texto no descalifican los saberes de Borrás, sino que en su interpretación invalidan los actos y sus protagonistas en los que ineficientemente el personaje desea participar o modificar. Lo que no puede ser descrito, nombrado, anticipado o contenido por los studia humanitatis se recoge, por oposición, como comprobación de los supuestos de este caudal de saberes. Lo que el vocabulario de Borrás es incapaz de contener pierde validez y existencia. Tomados como la desviación y la barbarie, se hacen presentes para asegurar y validar el locus de la razón, tras lo cual son eliminados del horizonte personal del personaje.

La racialización del proyecto académico de Borrás y su adopción de los valores occidentales -proceso que en el habla popular puertorriqueña se llama "dárselas de/ hacerse el blanquito"- es vital a la hora de entender los reclamos cognitivos y éticos a que se adscribe el personaje central que funge como narrador, en una escritura de corte autobiográfico. Para ello, retomemos el espacio de la memoria y su racialización.

Un ejemplo que nos permitirá una explicación de la elección racializada del personaje es la asistencia de Borrás a un toque de bomba, tipo de música que se adscribe a la ascendencia africana en Puerto Rico. Borrás asume la postura del antropólogo: describe al otro, deleitado por el virtuosismo, la procacidad y el ingenio del arte folclórico. Desde la memoria minuciosa relata/reconstruye conversaciones en la festividad, debates entre participantes y transcribe la gramática de la nostalgia ante la pérdida de la autenticidad de la festividad en cuestión. Transcribe las letras de las coplas en forma casi fonética, método privilegiado por la etnografía en una mirada atenta y sorprendida del estudioso no iniciado. Esto es, Borrás relata con una suerte de extranjería (de clase, de geografía y de adscripción racial).

Ante posibles alusiones a su ancestría negra detona en Borrás la búsqueda de identidad que dará como resultado su opción por "hacerse el blanquito", esto es, obviar su ancestría negra. Para aclarar este punto recordemos cuando atestigua/transcribe una conversación entre dos viejos sirvientes de latifundio cañero: José Dolores y Mano Encho. Mientras los obreros no educados y negros reflexionan sobre los vaivenes de la tenencia de tierras en los llanos costeros dedicados a la caña, comentan sobre la precariedad que tales cambios de fortuna arrojan sobre los de su clase, en especial sobre aquellos descendientes de esclavos. Estos últimos, según las memorias de Mano Encho, han asumido un papel protagónico en las luchas en el Caribe, si bien no se les reconoce así. Precisamente Borrás se sirve de esta escena para afirmar y diferenciar su propia categorización racial. De un lado usa su educación y su posición para acallar reclamos velados en la conversación. De otro lado, a partir de la taxonomía que se le adscribe en un diálogo transcrito en las memorias en el cual Borrás es contemplado por los dos personajes arriba mencionados y cuya adscripción negra se ha subrayado. Esta adscripción se logra 
ya a partir de sus usos lingüísticos, ya gracias a su descripción física. La conversación adquiere su relevancia en el proceso de racialización en fragmentos como el siguiente: "El negro ha sío el primerito en empuñar el machete, mijo. Aunque dispué el blanco se aproveche di lo que él luchó. Fijesen en Cuba. Dispué del triunfo, le dieron un arrempujoncito a los negros y se quearon ustedes los blancos con to. Y como lo oye el negro ha sío el primerito en empuñar el machete” (117, énfasis mío).

A partir de la mirada de un portador consciente de la ancestría negra, mirada excluyente, Borrás recobra de manera dubitativa su propia ancestría negra. Se nos describe cómo su mente, "aleccionada por el violento orgullo del improvisado cronista, quiere descubrir cierta rama en el árbol genealógico” (117). Sin embargo, la adscripción se mantiene como el proyecto posible de una propuesta dudosa. Contrasta con la certeza con que inscribe su apellido al abolengo francés cuando conoce a Pepiña. En aquella ocasión el personaje subraya su interés por la cultura, historia y vida cotidiana francesa, interés que le es genético.

El fragmento citado nos sirve además para acercarnos a las propuestas del texto sobre la memoria y su relación con la constitución de lo racial como categoría de diferenciación intranacional. La unión del relato personal y el hecho socio-histórico incide en el relato de cómo el acto desmemoriado y la memoria son pensados por los estudiosos de la identidad cultural y del pasado histórico con el mismo inquietante descredo del analista. La necesidad taxonómica de los modos de recordar nos ofrece una pulsación del distanciamiento que producen el olvido y la memoria en los relatos personales y en los nacionales. En este caso la historia no rescatada pertenece a una memoria descalificada, la de "un improvisado cronista".

Según el psicoanálisis clásico, la des/memoria manda su locus sígnico a través de dos gestos: el Verwerfung y los Verdrangung freudianos. Con el segundo gesto de producción simbólica las memorias dolorosas se representan a partir de disfraces. En el mecanismo de producción simbólica del Verwerfung el pasado problemático se manifesta a partir de un delirio hostil. Estas memorias se constituyen simultáneamente extranjeras, antagonistas y paradójicamente más fáciles de apropiar/entender/decodificar.

Juan Antonio Borrás, es un personaje memorioso que se encuentra escribiendo entre el Verwerfung y el Verdrängung para des/cubrir su participación en los terrores y errores de su propio protagonismo histórico. En este gesto propone la escritura como paso medio entre ambos relatos de la memoria. Llevar a cabo este proyecto requiere que las imágenes acuñadas por la violencia de su proceso reclamen para la escritura la función del Verwerfung. Sin embargo, la escritura funge de máscara de la memoria en una intentona por domesticar la amenaza del gesto de recordar. Desde la desmemoria amenazante recoge Borrás modalidades de escritura que combinadas producen las imágenes en que deambulan famélicos campesinos, oportunistas políticos, mujeres delicadas y rendidas a la posibilidad amorosa conjuntamente con incendios, huelgas, paisajes impregnados del sentimiento del beatus ille; imágenes voraces y siempre marcadas por consideraciones de tipo racial.

Así pues, el entorno del mundo cañero produce las imágenes amenazantes, mientras el hogar, el cafetal y el proceso de educación sentimental inciden en la producción simbólica del disfraz. En ambas esferas el relato de la racialización se constituye en paradigmático del manejo de la memoria y sus encarnaciones, de la posibilidad de manejo 
del conocimiento occidental. El manejo del conocimiento es crítico a la hora de dar cuenta de la herencia capaz de validar los saberes. El ejemplo más pulsante de esto es el personaje llamado Segundo, un peón letrado, hijo de una familia de racialización mixta quien representa con mayor insistencia el espacio amenazante de las ideas. Segundo adquirió su conocimiento en espacios no institucionales, de manos de un anciano revolucionario, don Hipólito y más tarde conducido por su propia avidez intelectual. Es capaz de citar a Marx y a Niesztche, pero su conocimiento se constituye en un arma que apunta a su propia muerte.

Borrás, por el contrario, coincide con las propuestas básicas del obrero. Pero en su caso la letra misma, adquirida por medios legítimos e institucionales -la tenencia de tierra y su incorporación a los valores de occidente- le provee de distancia, le evita el gesto redentorista y valida sus saberes:

\begin{abstract}
El otro día oí a Segundo decir: "Nos amarga la caña”. Aunque me molestó la frase, pensándolo bien me doy cuenta de la verdad que encierra. ¡Aquí los hombres son siervos! Yo nunca he creído en la olocracia; sin embargo, me parece que la peonada tiene derecho a un poco más de felicidad. Es horroroso que viva en tan terrible pauperismo. [...] Segundo tiene razón en pensar así: me lo grita la conciencia. Tiene razón, sin embargo, no quiero reconocerlo.[...] No he vuelto a casa de don Polo; he evitado hasta el pasar por frente a su casa. No quiero verle, no quiero ver su sillón de ruedas[...] Solo se le ocurren sueños irrealizables y confunde la realidad con la fantasía. Eso. Ayer no más estuve pensándole un nombre rimbombante como Alonso Quijano se pensó el suyo, y, entre risas, se me ocurrió llamarle don Cándido de la Palma Chica. (140)
\end{abstract}

La letra adquirida gracias a los studia humanitatis le permite a Borrás eludir el discurso de la injusticia social a favor del referencial letrado en sí mismo. Termina el asunto con una broma, pues la letra como locus le permite distanciarse, asumirse testigo no participante, casi cronista capaz de recoger el caudal de saberes y disponerlo para tomar la situación inmediata y asumirla dentro de categorías narrativas. La alusión al texto cervantino descalifica al aludido mientras da poder a aquel capaz de citar y reescribir el texto. Por el contrario, Segundo, el peón de racialidades mezcladas educado por don Polo, visionario soñador que sirve de conciencia ideológica para Borrás, incita a la huelga y a la quema del ingenio y, finalmente, es muerto de un balazo cuando arremete contra el joven agrónomo. De un lado la letra, caída en manos ilegítimas como las de Segundo, encauza su inconformidad hacia lo trágico; de otro lado, representa el gesto de mártir al que Borrás aspira, pero que no consuma, pues el apego a la tenencia de tierras que legitima su herencia paterna incapacitan/convierten en innecesario el gesto de mártir. Pepiña, la mujer a que ambos hombres aspiran, se decide por Borrás; clase, educación institucionalizada y raza se validan sobre la posibilidad amenazante de Segundo, letrado autodidacta, mestizo, sin tierras e ilegítimo.

Así tenemos que el lenguaje racial de identificación del personaje divide entre lo amenazante y lo domesticable. Las etnicidades manifiestas en el texto y aquellas que el personaje reclama para sí legitiman conocimientos y aseguran sobrevivencia. De la genealogía de Juan Antonio Borrás alcanzamos a saber que uno de sus abuelos fue francés 
y que tiene una pequeña dosis de herencia africana. Esta adscripción racial dual parece permear el gesto escritural, la vida sentimental y las posturas desarrollistas sobre el país. Incluso incide en el deseo, que está unido a discursos en que convergen la sexualidad y la producción de nuevas formas de poder. La división de clases/apropiación de educación occidental escinde los discursos del deseo, permitiendo una distinción entre los blancos subalternos y sus contrapartes de clase media o alta. La dicotomía Delmira/Pepiña ilustra este enunciado.

La categoría de lo femenino participa de la inteligibilidad, pero sin embargo se distingue de lo inteligible -no ocupa de lleno esa categoría, pues localiza su ontología en los sentidos. Lo que define lo femenino como categoría cognitiva es su capacidad de nutrir, de posibilitar la existencia de otros seres. Tiene en el texto identidad intercambiable, pues posee una esencial permeabilidad, infinitamente transformable, inherentemente dispuesta a las porosidades y especificidades con que lo concreto tiñe su ontología particular. Funciona, primariamente, como receptáculo, un locus que se nutre en las transiciones necesarias para emerger como ciudadana, esto es, quien incuba y asegura la transmisión de los valores de clase, unidos a los físicos, a los que aspira Borrás al construir su utopía. El cuerpo femenino tiende a asumirse desde la patología y su capacidad reproductora. Es parte fundamental del proceso de "hacerse el blanquito”, de posibilitar dicho ademán. La posesión de la mujer determina cercanía -cuando no plena incorporación-a la gramática de lo blanco. Asimismo, su posibilidad de incubar vida presupone la consecución del proyecto racial, educativo y de clase de Borrás. Se trata de la fase de concreción de las ideas propuestas desde los studia humanitatis modélicos en el texto.

El ente femenino racializado no deja de proyectarse, por todo ello, como espacio del imaginario en el cual las fantasías erotizantes encuentran como parte de su discurso la histeria y lo indisciplinado. El texto insiste en el análisis de los personajes femeninos desde una preceptiva de la tecnología reproductiva cuasi decimonónica, que nos incita a reflexionar sobre la gramática de la heteronormatividad y su relación con la racialización. En efecto, diversos personajes femeninos representan distintas somatizaciones mediadas no solo por los determinantes del género, sino también por el origen y la geografía. El proceso de conseguir una pareja adecuada para Borrás sufre de un escrutinio tan pormenorizado que es casi un manual de razonamiento de clase, ancestría y raza de la mujer ideal. Las escenas y representaciones de los personajes femeninos sirven, además, para entender la sexualidad mediada por percepciones de clase y sus regulaciones, como parte de la jerarquización elaborada a partir de la noción de raza, constructo que en las sociedades democráticas sirve para detener el flujo de capas bajas hacia los bienes culturales y económicos.

Como nos recuerda Foucault, el discurso racial es inmanente al lenguaje de las clases. Clase, raza y género son términos polisémicos, polivalentes y de etimologías variadas, de acuerdo con el locus que las invoque. El texto de Laguerre recoge una variedad importante de estas representaciones en la sociedad puertorriqueña de mediados del siglo pasado, con su carga colonial particular. En los mismos, la representación de lo salvaje, lo promiscuo, lo licencioso y las llamadas verdades naturales éticas son parte de la visión de un Puerto Rico que debe ser mejorado, voz de alerta de conductas y sectores de la población que deben ser higienizados y regulados cuando no proscritos y eliminados. Estos relatos de la 
ingobernabilidad evidencian cómo los cuerpos de la burguesía y la clase media se delinean con una sexualidad distintiva y correcta.

En el espacio colonial puertorriqueño de mediados del siglo xx los límites raciales, de clase y género no son tan claros como parece proponer el texto. Laguerre recurre entonces a la ancestría para determinar la legitimación de las conductas éticas. Delmira, personaje femenino que se constituye en una summa de tipos como el alma gemela, la solterona digna, la sensual íntima y el cuerpo colapsante, es racialmente mixta e hija de una relación extramarital. Rodeada de sus tías solteronas, es producto de una relación que socialmente fue desaprobada sobre prejuicios de clase y rivalidades de raigambre socioeconómica y racial.

La somatización de lo femenino/racialmente mixto en el caso de Delmira implica su caracterización como objeto del deseo erótico, a la par que muestra a la mujer de origen europeo -Pepiña- como una criatura de peculiar autodominio en la expresión de su sexualidad. La construcción de la mujer racialmente mixta como un ser pasivo de erótica permite el viaje de Borrás como voyeur en el mundo de lo femenino, sin que esa inclusión implique retar la masculinidad; más bien permite la inscripción en el texto de una retórica misógina de blanqueamiento.

Las imágenes seleccionadas para representar a Delmira conforman los elementos constitutivos de lo que estudiosos del siglo xIx han nominado "la mujer colapsada". El término lo recoge Bram Dijkstra para las imágenes pictóricas producidas por el prerrafaelismo y su resonancia de la ética victoriana. Se refiere a imágenes como la de Flaming June, de Lord Leighton. Dijkstra acuña el término “mujer colapsante” para describir: "an image which serves truly as the apotheosis of feminine lassitude" (73).

Delmira se constituye en este texto en imaginario femenino con muchos de los ornamentos atribuidos a la mujer doméstica pero, de alguna manera, el peso de su materialidad y su autoerótica se construyen como elementos suficientes para proscribirla y convertirla en un cuerpo que exhibe cierta extenuación propia, adormilada, de una aparente esterilidad. Borrás la observa una noche entregada a ritos sensuales, en los que hace claro su deseo por el joven agrónomo. La diversidad de mitos sobre las sexualidades de la mujer racialmente mixta se vuelve vigente. A la medida de ello, la mujer muere víctima de la pasión insatisfecha: el locus de la mulata trágica se cumple.

Pepiña, por su parte, representa la política de Borrás de "hacerse el blanquito” por asociación marital. Esta estrategia es una tecnología biogenética de peso en el Caribe con larga tradición enraizada en el positivismo esgrimido por pensadores decimonónicos. Pepiña asume igualmente códigos de procesos racializados. Elige como esposo al portador de los studia humanitatis, modelo cognitivo que sirve como espacio restrictivo para su modelación de lo femenino a la par que se constituye en vínculo con su espacio de origen, París. Pepiña es capaz de reconocer el talento y aun el atractivo de Segundo, pero su apego sentimental se desarrolla por Borrás quien porta modelos cognitivos europeos y aspiraciones de clase y racialización que se apañan con los mismos. Es una mujer saludable, realista, con sensibilidad y belleza que mira los excesos de la femineidad exhibida por las mujeres criollas con asombro y desdén. Moldeada por los studia humanitatis representa un ideal de femineidad donde pudor e inteligencia contenida se unen a raza y linaje europeos. 
Por todo lo antes expuesto, el saber se media por aspiraciones de clases y es interrogado en el mismo texto. De un lado, Borrás explica sus sentimientos encontrados entre su sed de ascender en el mundo del cañaveral y su sentido ético-social sobre las condiciones de los obreros - "la peonada”, como le llama con insistencia en el escrito pseudoautobiográfico- a partir del dialectismo que el pensamiento occidental presupone. Por otro lado, Segundo, un obrero que lee a Marx y alude a textos anarquistas, termina muerto de un balazo tras incitar un levantamiento, como hemos explicado una líneas más arriba. El saber humanístico puede ser un arma peligrosa, pues mientras para Borrás los problemas éticos incitados por el humanismo son una cuestión que la geografía atenúa y desaparecen al mudarse de los llanos costeros a la Cordillera Central, para Segundo equivalen a la muerte. El saber le permite a Borrás la racialización de sus dudas sobre el discurrir histórico, mientras que para Segundo presuponen tomar acción.

El recurso intelectual de reflexionar sin participar es subrayado como válido. Pensemos en la reflexión de Borrás sobre la racialización de la historia y el perfil racial del Caribe. Reconoce un apego al linaje africano a la par que coloca como un problema la llamada mezcla de razas, el doblete ideológico puede apreciarse en fragmentos como el que sigue: "La mezcla de sangre es un problema integralmente americano. Es preciso hacer el orgullo que nos falta. Mientras no levantemos ese orgullo fracasaremos en las responsabilidades de la vida” (118-9).

A partir de esta premisa de un locus de anomalía ejemplariza los logros intelectuales de estudiantes colegas suyos que notablemente pertenecían a espacios racializados y de margen, mientras fustiga a quienes intentan acallar la mezcla racial. Borrás evita identificarse abiertamente con un grupo o el otro, mientras mantiene una valoración occidental para dar cuenta del talento de aquellos inter-raza, esto es su potencial intelectual. Este recurso -constante desde el siglo xix- implica que la capacidad para someterse a los sistemas disciplinarios de higienización y regulación cognitiva y laboral implicaban la capacidad de acceder al espacio humano/civilizatorio.

Los discursos de sexualidad en el ámbito colonial populista en que Laguerre escribe son productores de poderes de clase y raza, no meramente reflejos de éste. La gramática de la sexualidad en este texto es un proyecto con especificaciones de clase y género, que maneja -a la par que es producido por- un grupo de anhelos/deseos. La atención a los discursos y propuestas de la sexualidad captura en parte la enorme complejidad de una estructura en la que la imitación se constituye en burla, la ambivalencia en agresión y la nostalgia cultural en deseo y prohibición de lo sexual.

En el lado opuesto del espectro, los peones, descritos como sombras de racialidades mixtas, exhiben toda clase de enfermedades y pobrezas. En efecto, los discursos sobre contagios sexuales, contaminación moral y reproducción “estéril” no son aplicables a toda sexualidad en el texto sino que se especifica su relación con la pobreza de "la peonada". Estos discursos circulan en un campo de distinción de clase y raza en el cual el pronunciamiento didáctico sobre amores sexuales, contaminación, pobreza, abstinencia y reproducción es constante. El semen derramado provoca juicio ético y distinciones entre la virtud de la clase media, educada bajo los saberes occidentales y “ablanquitonada”, y la peonada de clase baja, racializada más allá de su pigmentación cutánea, para crear un argumento que aúna las nociones acuñadas de lo inmoral con las penurias económicas. 
En la premisa textual de la narrativa de Borrás puede trazarse cómo el deseo sexual es incitado a la vez que provoca prácticas y discursividades regulatorias. Se da fe tanto de la regulación de deseo como de su manufactura. Las relaciones de poder-como nos han advertido Foucault y Lacan en otras coordenadas- pueden ser explicadas como parte de la sublimación de los deseos reprimidos de Borrás, cuyas ideas conservan una fidelidad pasmosa con el populismo educado propio del Estado Libre Asociado que participa de una misión moralizante y restrictiva durante el Puerto Rico de los años cincuenta.

La excepción al asunto racial como contrapunto ordenador de valores éticos parecería ser José Dolores, viejo sirviente negro de las hermanas Alzamora que hospedan a Borrás. Se propone en el texto una relación filial entre el protagonista y el sirviente:

José Dolores me ha tomado un cariño paternal. Como ha nacido en Santa Rosa y ha vivido casi toda su vida aquí, es la confianza de las señoritas a quienes sirve hasta de consejero. ¡Admirable José Dolores, tan bondadoso y suave! Yo, desde luego, le quiero como a un buen padre. José Dolores me pidió permiso para llamarme Juanito, y yo gustoso, se lo concedí. Hasta le pedí que me tutease. Comprendo que en el fondo soy muy sentimental y cualquier manifestación de afecto me conmueve mucho. (42)

Es una paternidad apócrifa y sustituta, ya que su padre real lo mantiene en la distancia. La sustitución del pater familias por un hombre negro resulta importante, pues historia de manera apócrifa las racialidades de las cuales Borrás se aleja. El hombre negro propone narrativas sobre la familia que mantiene a Borrás como huésped, le vincula con el amor de las solteronas y valida la presencia del joven agrónomo en el espacio cañero. Resulta curioso, pues, que José Dolores nunca pierda su función servil: le prepara el caballo a Borrás para que pueda supervisar a los obreros y habla solo cuando éste lo interpela y va caminando tras Borrás, jinete en soberbio caballo, para traer al último de vuelta. Incluso sus reclamos y el decaimiento de su estado anímico quedan en el espacio del gesto de lo irremediable y el acomodo.

Encontramos en el texto arriba citado los supuestos étnicos que fortalecen la posicionalidad de servidumbre de los esclavos y sus descendientes. Esta imagen, que la crítica afro-norteamericana ha dado en llamar el "Uncle Tom”, incide en la imagen impulsada desde el recuento de la institución esclavizadora consonante con la familia feliz. Si bien la voz de José Dolores se presenta escasamente y de manera fragmentaria, su singularidad es tomada como una abstracción de la voz de aquellos descendientes de esclavos que permanecen bajo la tutela de la familia blanca. Raza, esclavitud y servidumbre se convierten así en encarnaciones intercambiables del mismo gesto, la interpretación racial de la servidumbre. Tenemos, pues, que José Dolores no solo habla por otros siervos, sino que habla por y desde lo racial. Así, mientras el texto parece presentar una interracialidad donde conviven personajes del amplio espectro humano que percibimos en la realidad isleña extensional, podemos atestiguar la sutil jerarquización a partir del delineamiento del color.

El siervo ocupa en el espacio de constitución de lo nacional/racial una posición en la cual funciona como metáfora de lo que debe ser corregido y alegoría de lo que debe ser excluido. La inclusión de "la peonada” como un personaje colectivo, en el que se delinean 
una sexualidad animalizada, una reproducción sin freno y poca voluntad o capacidad de discernimiento. La raigambre malthusiana de esta aseveración no puede ser más clara.

La raza, pues, sirve como una metáfora cargada de peso alegórico, a la par que un mecanismo para explicar y nombrar los límites y los actos de los personajes. Dentro de ese proceso la escritura se constituye en un gesto racializado en sí mismo. Pensemos, para sustentar esta hipótesis, en cuál es la función del escritor. El escritor asume una función cercana a aquella descrita por Sara Suleri como propia de quien ejerce la escritura en el locus poscolonial: "To tell the history of another is to be pressed against the limits of one's own -thus culture learns that terror has a local habitation and a name” (2). ${ }^{3}$

La letra se constituye en La llamarada, en el espacio para dilucidar/amansar el terror del recuerdo. El gesto de escritura, en marca civilatoria de distinción, regulación y separación entre el sujeto que narra, los hechos relatados y aquellos que los protagonizan, pero no los relatan. La letra se constituye, además, en mecanismo de acercamiento al pensamiento civilizatorio occidental, y, por ende, es el brazo efectivo para posibilitar el blanqueamiento del personaje narrador. La letra es, como sabemos, eje central de la jerarquía de poderes ejercitada desde los studia humanitatis en que el protagonista se constituye. Si bien al personaje se lo define como “tecnócrata”, el texto no recoge ninguna preocupación en esa área, antes bien, sus preocupaciones se restringen al espacio cognitivo delineado por los estudios humanísticos tal y como han sido propuestos por la academia a partir del Renacimiento. Como sabemos, esta restricción disciplinaria creció bajo el ala del llamado mejoramiento de lo definido como "lo humano". La memoria permitida es la que se muestra tras el disfraz inofensivo, la que recurre a la metáfora, la que exhibe los silenciamientos y el ideario de los studia humanitatis. La letra se posibilita solo cuando puede marcarse lejanía con la acción, cuando el gesto participatorio cede al distanciamiento. A este proceso alude Borrás constantemente en fragmentos de este tipo:

Y aquel día, como que una emoción nunca antes sentida me hizo cambiar de rumbos. Fue un sacudimiento bárbaro en el espíritu que malogró el petulante "héroe del oeste”, que me hizo descubrir imprevistas angustias, que me permitió saber que muchas veces andamos lejos de nosotros mismos, que me asomó bruscamente a la gran tragedia de unas vidas. Verán ustedes. (61)

El texto se dirige a un "ustedes” letrado, público interesado en estas memorias, lectores aleccionados sobre este viaje al mundo cañero y sus injusticias. La transformación de Borrás tiene visos éticos pues pasa de ser petulante/héroe a observador/narrador de tragedias humanas.

La selección del mecanismo autobiográfico igualmente incide en la racialización de esta escritura y el proceso de "hacerse el blanquito". Pasar por blanco o "hacerse el blanquito" es un gesto de insatisfacción para el protagonista de La llamarada, pero tal insatisfacción no está enraizada en una irresistible compulsión, más bien parte de la esencia racial, biológica y cultural que se construye para legitimar jerarquías dentro de su

\footnotetext{
${ }^{3}$ La integración de la teoría poscolonial en nuestra lectura puede resultar cuestionable, pues las coordenadas de esta escritura se dan en los límites coloniales.
} 
espacio nacional. En dicho proceso, la ascendencia europea legitima accesos mientras permite exclusiones importantes. En el texto en cuestión se hace escrutinio del proceso de la subjetivación racial, tanto en términos de la producción de un sujeto moderno como parte de la apropiación de la escritura autobiográfica, y de la ruptura con algunas especificaciones de la subjetivación racial.

Por ello, la decisión escritural de seleccionar como medio expresivo una autobiografía fictiva no es insignificante: el género, históricamente, posee una relación particularmente estrecha con el concepto occidental de lo racional y del sujeto autónomo. La teorización tradicional sobre la autobiografía toma al sujeto no solo como objeto de representación, sino también como fuente de significaciones. Georges Gusdorf, por ejemplo, reclama que: "the autobiographer strains toward a complete and coherent expression of his entire destiny....[requiring] a man to take a distance with regard to himself in order to reconstitute himself in the focus of his special unity and identity across time” (49). Según esta postura, el propósito de la escritura autobiográfica no es la verdad histórica, antes bien, "the truth of the man, for it is first of all the man who is in question” (16). Laguerre, en esta pseudoautobiografía, no violenta el basamento metafísico del género como posteriormente hará mucha escritura posmoderna. En su lugar, el personaje Borrás coloca en el desconocimiento los datos de su vida y relata solo impresiones; la presencia vital se reescribe, el sujeto originario cuya subjetividad debe dar coherencia a la narrativa se asume desde la incertidumbre.

El problema del sujeto originario incide con constancia a través del texto y se expresa en su nominación Borrás. El nombre apela a borramiento, lo que recuerda la ausencia del padre, recuérdese que el personaje nunca gana o acepta del todo su filiación. Esta ausencia de nombre/padre y genealogía, de reconocimiento paterno, está ligada al gesto de "hacerse el blanquito”, de pasar por blanco. El carácter secreto del origen coincide con la insistencia de la política de “mejoramiento de la raza” que exhibe el personaje, por ejemplo, al escoger su cónyuge o al explicitar solo una parte de su genealogía.

El nombre está desligado de la memoria y unido a la desmemoria en este texto. Ese carácter secreto que rodea el nombre -el padre, el origen- es paralela al silenciamiento de identidades que conlleva "hacerse el blanquito". Alternativamente, puede ser también como una marca de "indexicalidad” de la suspensión de las funciones subjetivas del nombre. El nombre -o al menos el gesto de cobijarse en el nombre del padre- asegura continuidad de responsabilidad y agencia en un transcurso del tiempo trans-sujeto. En una sociedad patriarcal indica las relaciones sociales relativas a la pertenencia familiar que localiza y especifica a un sujeto en relación con otros. El nombre media entre sensaciones o relaciones momentáneas y la necesidad de continuidad social y coherencia delineada por encima de lo temporal. Como asegura Lacan, "the name is the time of the object” (119). Está presente en el texto el recurso de dar genealogía a los personajes secundarios, mientras para Borrás solo existe la innombrabilidad de su condición genética.

En una sociedad donde la genealogía es parte de la racialización del sujeto, su ausencia parece significar una doble negación: de identidad-racial y de subjetividad. La posibilidad de "hacerse el blanquito" no solo incide en esa doble negación sino que, más importante aún, rompe con el binarismo blanco o negro que supone la división racial. Borrás sobreimpone en su proceso de pasarse por blanquito ambas posibilidades, a la par. 
“Hacerse el blanquito” en La llamarada es un proceso de movilidad geográfica, de movilidad social y de movilidad del sujeto por su propia ontología. Hacerse en cuanto verbo implica, de un lado, una construcción en movimiento continuo auto-reflexiva; en su implicación racial "hacerse el blanquito" significa ser tomado por, crearse una identidad de, esto es, asediar una representación de sustitución. Ambos sentidos, en capas superimpuestas, aparecen en la construcción de Borrás. Desde el principio del texto la movilidad continua del personaje -descripción de medios de transporte y su rapidez, o su valor como insignias de poder- sugiere que la geografía del proceso de racialización no es tan solo una metáfora y que apropiarse de insignias del blanquito es un proceso en un continuum. Posicionalidad y movilidad son dos coordenadas para hallar el eje de tropismo del personaje y de su apoderamiento del locus del blanquito. El movimiento del personaje narrador entre distintos estadios de la "blanquitud" nos muestran cómo la racialización es una construcción social, tal y como las teorías raciales de Gates han insistido desde los ochenta del pasado siglo.

El texto de Laguerre provee una serie de descripciones del intento casi desesperado de Borrás por que su blancura, apropiada étnica y racialmente, conlleve el significante de su innata superioridad; es decir, que esta sea (a)firmada a partir de la exhibición de las insignias de ser blanco, categoría cultural antes que biológica que puede ser asumida a partir de educación, tenencia de tierras y relaciones sociales. Esta economía racial propuesta por Borrás tiene dos vertientes principales: de un lado subrayar su propia superioridad física y racial; y de otro lado, asegurarse que el espacio de contrapunto -lo negro- no pierda ni su identidad ni su locus.

El drama de "hacerse el blanquito" muestra precisamente la confrontación entre dos perspectivas epistemológicas, que pueden resumirse en la confrontación entre apariencia como verdad y apariencia como falsedad. "Hacerse el blanquito" es una expresión figurativa de la ruptura con cualquier mecanismo instituido para reclamar una verdad racial. El asumir que hay alguna verdad del ser depositada bajo la construcción racial y que corresponde a la apariencia, descansa en la separación misma entre apariencia y ser, separación que se presume abolida, pues siempre está la posibilidad de que dicha separación produzca una ruptura que muestre el juego de apariencias que le conecta con otras verdades reclamadas desde la racialización. Verdades tales como nación y posicionalidad que en ese discurso igualmente se tambalean.

El proceso autobiográfico se constituye en una metodología de (de)sedimentación. La constante alusión a genealogías familiares de los personajes secundarios posibilita la constitución del propio Borrás como un sujeto transracial. En ese mismo sentido, la descripción del sujeto femenino tiene la función de constituir el locus hogareño en un conjunto de marcas de racialización de importancia vital. Lo femenino y lo masculino se sitúan en este texto como parte del binarismo reclamado por Occidente que caracteriza el grueso del pensamiento a que hacen referencia los studia humanitatis, el cual incluye la oposición entre lo sensible y lo inteligible, lo material y lo ideal, lo mortal y lo divino, que de alguna manera puede resumirse en la dicotomía fundamental del imperfecto mundo material y el perfecto mundo de la razón.

La oposición entre lo inteligible y permanente -el mundo de las ideas, para apropiarnos el concepto platónico- y lo que es sensible, visible, tangible, perecedero, 
además de sujeto a cambios, puede parecer un modelo preclaro en el texto. El mundo de la razón ocupado por Borrás, representante de los studia humanitatis y sus propuestas de miscigenación; los otros y las otras participando del mundo sensible. Pero este modelo cuenta en el texto con el espacio de liminaridad de encuentro entre ambos mundos: la escritura dedicada específicamente a la descripción de lo femenino y las racializaciones que se desprenden del mundo social. Atestiguamos la domesticación de la contradicción tras el logro eficaz de la estrategia tantas veces blandida en el Caribe de "hacerse el blanquito”.

\section{Bibliografía}

Bhabha, Homi. Nation and Narration. London: Routledge, 1990.

Bowie, M. Lacan. London: Harper-Collins, 1991.

Dijkstra, Bram. Idols of Perversity: Fantasies of Feminine Perversity in Fin-de-Sie'cle Culture. New York: Oxford University Press, 1986.

Fanon, Frantz. Piel negra, máscaras blancas. La Habana: Instituto del Libro, 1967.

Foucault, M. Language, Counter-memory and Practice.Donald Bouchard, ed. Ithaca: Cornell University Press, 1977.

Gates, Henry Louis. “Race”, Writing and Difference. Chicago: University of Chicago Press, 1986.

Gusdorf, Georges. “Conditions and Limits of Autobiography”. Autobiography, Essays Theoretical and Critical. James Olney, ed. Princeton: Princeton University Press, 1980.

Heidegger, Martin. “Letter on Humanism”. Basic Writings. David Farrel, ed. London: Routlegde, 1977.

Lacan, J. Ecrits, A Selection. Alan Sheridan, ed. London: Tavistock, 1977.

Laguerre, Enrique. La llamarada. Obras Completas. Río Piedras, Puerto Rico: Instituto de Cultura, 1992.

Sureli, Sara. The Rhetoric of English India. Chicago: University of Chicago Press, 1992. 